\title{
TECHNICAL EFFICIENCY OF SERBIAN DAIRY PROCESSING INDUSTRY
}

\author{
Rade Popović ${ }^{1}$, Dalibor Panić ${ }^{2}$ \\ *Corresponding author E-mail: popovicr@ef.uns.ac.rs
}

\begin{abstract}
A R T I C L E I N F O
A B S T R A C T

Original Article

Received: 2 February 2018

Serbian dairy processing sector is passing through

Accepted: 18 May 2018 significant structural changes in last couple decades. Concentration, vertical coordination and integration become a main characteristics. The main goal of the paper doi:10.5937/ekoPolj1802569P

UDC 65.011.46:637.1(497.11) is to explore technical efficiency of 91 Serbian dairy processors in sample by non-parametric method Data

Keywords:

dairy, processors, efficiency, DEA, Serbia envelopment analysis. Data were collected from financial reports of dairy companies in 2015. All dairy companies were divided in 4 groups: micro, small, middle and big. The empirical results indicate that $16.5 \%$ of companies were technically efficient. This study shows that efficient JEL: L25 companies exist across all size groups, and while small companies suffer from input inefficiency and insufficient size of business, the bigger companies are over invested.
\end{abstract}

(C) 2018 EA. All rights reserved.

\section{Introduction}

Among all dairy species, cow milk is the most important type in Serbia with $96 \%$ share in human diet, while goat and sheep milk has marginally shares. Average yearly consumption in Serbia in 2015 was $222 \mathrm{~kg}$ per capita, calculated in milk equivalents (ME). Under milk equivalent is implied amount of liquid milk used to produce dairy products. At same time in EU-28 average consumption was $306 \mathrm{~kg} \mathrm{ME} /$ capita/year ranging from $178 \mathrm{~kg} \mathrm{ME} /$ capita/year in Hungary to $638 \mathrm{~kg}$ ME/capita/year in Ireland (Hemme, 2016).

Milk production in Serbia is based mainly on family farms in two different production regions, lowland and highland. Small farms with up to 9 cows producing $2 / 3$ of total milk in Serbia (Popovic, 2014). Raw milk market is one of significant challenges for processors. In couple recent decades big dairy companies, followed latterly by middle sized dairies invested significant effort to secure quantity and quality of row milk supply.

1 Rade Popović, PhD, Associate Professor, University of Novi Sad, Faculty of Economics in Subotica, Segedinski put 9-11, 24000 Subotica, Serbia, Phone: +38124628064, E-mail: popovicr@ef.uns.ac.rs, ORCID ID (https://orcid.org/0000-0002-0879-1340)

2 Dalibor Panić, MsC, PhD student of economics, University of Novi Sad, Faculty of Economics in Subotica, Segedinski put 9-11, 24000 Subotica, Serbia, Phone: +38124628064, E-mail: dalibor226@gmail.com 
Dairy industry in Serbia is consisted from 114 companies, ranged from micro to big. While dairy industry in the most of EU and other developed countries is dominantly or completely based on cooperatives, in Serbia they don't exist in dairy sector. Similar situation is in almost all other food sectors except several new generation cooperatives in fruit sector. Dairy processing industry in Serbia is characterized by several trends. Milk is by $2 / 3$ processing in dairy plants while significant amount still used and processed on farms. Processing share of dairy companies during years increasing, on account of milk processed and used on farms. Number of dairy companies decreasing partially as result of concentration process, especially in case of big companies, like Imlek.

Several small and middle sized companies use strategies more oriented into vertical integrations. Some companies invested in downstream vertical integration trying to secure input supply sector and some quite successful companies invest in upstream vertical integration with goal to establish own retail network (Popovic, Panic, 2015). Small dairy shops help them to bypass highly concentrated retail companies and their market power. Usually established on frequent places, like green markets or frequent pedestrian areas, dairy shops shorten period from row milk payment to cash revenue from dairy products sold and increase profitability of dairy companies.

Dairy processing sector in Serbia lost market power a decade ago (Popovic, Radovanov, 2010). Under pressure from retailers and increased competition, processors had to focused more on technology and market efficiency.

Studies of efficiency of dairy processing industry are not numerous, while studies of dairy farms are well represented. In case of Serbia efficiency of dairy processing industry is not yet exploited, but efficiency of dairy farms was topic of several researches (Popovic, 2006, 2013). Some authors investigated productivity of dairy industry like Barać and Muminović (2013). Measuring the impact of capital investments on different quantitative and qualitative features of dairy processing companies in Slovenia, Croatia and Serbia stated that capital investments per employee significantly increase productivity measured by EBITDA and personnel costs.

Baran (2012) evaluated efficiency of the production scale of Polish milk processing companies in 1999-2010 using non-parametric methods. The non-parametric approach stemmed from linear programming Data Envelopment Analysis (DEA) method. The study involving a sample of 743 objects revealed increasing returns to scale observable in the Polish dairy sector. Author emphasizes that the gap between the Polish milk processing and leading European countries implies that there is a need for improved efficiency and international competitiveness.

Investigating technical efficiency among dairy cooperatives and investor owned firms in: Belgium, Netherland, Denmark, Germany and France during period 1995-2005 Soboh, Lansink and Dijk (2014) applied stochastic frontier analysis (SFA). Results for 360 cooperatives and 861 investor owned firms shows that dairy cooperatives were slightly less efficient. Both cooperatives and investor owned firms are characterised by decreasing return to scale. 
Špička (2015) evaluated the technical efficiency improvement of the Czech, Polish and Slovak corporate milk processors in the period 2008 - 2013 to identify the possible source of low competitiveness of the Czech and Slovak milk processors towards Poland. The analysis was based on individual data of 130 milk processors. The sample covers medium-sized and large companies only. Deflated data on sales, material and energy costs, staff costs and depreciation were used as output and inputs for efficiency calculation. The DEA method was used for calculation of technical efficiency, Malmquist index estimated the efficiency change in time. Two-sample t-test and the analysis of variance enhanced by Sheffe's test verified the statistical hypotheses. The results proved that the Czech and Slovak milk processors had lower efficiency improvement than Polish companies. Investment activity did not significantly affect the efficiency improvement.

Silva, Arzubi and Berbel (2004) measured the Azores dairy farms technical efficiency by applying a non-parametric efficiency analysis to a panel data of 122 dairy farms from the Azores, Portugal for 1996. Azores islands belong to the Portuguese territory and the main economic activity is dairy farming. The analysis used DEA with constant and variable returns to scale models, with an input-oriented model approach. Two outputs (milk production and subsidies) and three inputs (agricultural area, number of dairy cows, variable and fixed cost) were considered relevant. The results suggested that the average technical efficiency was very low $(66,4 \%)$ compared with published research data and only a few (7\%) dairy farms were found to be efficient.

Hambrusch, Kirner and Ortner (2006) used Data envelopment analysis (DEA) to measure efficiency scores of Austrian dairy farms and to examine the relationship between efficiency and farm size. Data envelopment analysis (DEA) was applied to a sample of 222 highly specialised dairy farms. The results showed an average technical efficiency of $79 \%$ and a scale efficiency of $94 \%$. According to the results, they concluded that natural conditions and management practices had a stronger impact on technical efficiency than farm size. An analysis of returns to scale revealed that $18 \%$ of the sample farms were operating at constant returns to scale, $9 \%$ above and $73 \%$ below efficient scale.

Candemir and Koyubenbe, (2006) measured the production efficiency of dairy farms in the province of Izmir, Turkey, based on cross section data of 2003 covering 80 farms chosen by the method of proportional sampling. They used two types of DEA model: model with constant returns to scale and model with variable returns to scale, using three outputs and seven inputs. Exploration showed that forty nine percent of the dairy farms appeared to be fully efficient according to the assumption of constant return to scale (CRS). The average efficiency indices obtained under CRS and variable return to scale (VRS) were 0.934 and 0.954 , respectively. Mean scale efficiency, on the other hand, was 0.978 . Out of the selected dairy farms $21.2 \%$ were observed to be efficient in measuring the efficiency of single output milk production. Average efficiency indices under CRS and VRS and scale efficiency index were measured to be $0.782,0.832$ and 0.938 , respectively. 
Kelly et al. (2012) in their study tried to determine the levels of technical efficiency on a sample of Irish dairy farms utilizing Data Envelopment Analysis (DEA) and to identify key management and production factors that differ between producers indentified as efficient and inefficient. DEA was used to generate technical efficiency scores under assumptions of both constant returns to scale (CRS) and variable returns to scale (VRS). The average technical efficiency score was 0.785 under CRS and 0.833 under VRS. Key production characteristics of efficient and inefficient producers were compared using an analysis of variance. More technically efficient producers used less input per unit of output, had higher production per cow and per hectare and had a longer grazing season, a higher milk quality standard, were more likely to have participated in milk recording and had greater land quality compared to the inefficient producers.

Al-Sharafat (2013) estimated the level of technical efficiency (TE) of dairy producing farms in Jordan by applying the stochastic production frontier (SPF) methodology to a sample of 100 dairy farms. The results of this study indicated that technical efficiency of milk production by most of dairy farms in Jordan is low. The mean technical efficiency was estimated to be only $39.5 \%$ for the sampled dairy farms. The results showed that there was a substantial technical inefficiency on dairy farms in Jordan suggesting inefficient production. According to his opinion, farmer's level of education, farmer's farming experience, farmer's contact with an extension services and herd size are the main determinants associated with TE in the sampled dairy farms. He suggests that technical efficiency can be improved through provision of education, training and orientation of the farmers toward dairy farming practices.

Aldeseit (2013) evaluated the performance of sampled dairy farms using farm level technical and scale input oriented efficiencies. To achieved the objective of the study Data Envelopment Analysis (DEA) was used to analyze data collected from 120 dairy farms in Jordan. Scale efficiency scores were estimated using constant return to scale and variable return to scale DEA models. The results revealed that the sampled farms were not operating at an optimal size. On average, the scale efficiency estimated at approximately 0.66 , indicating scale-inefficiency under both constant returns to scale and variable returns to scale. Author emphasized this inefficiency indicates that the sampled dairy producers were overusing inputs to produce their level of output. Also, increase scale of operation dairy farmers in Jordan should increase the overall degree of technical efficiency. He suggests that extension services can assist in identifying the best management practices on how to improve farms technical efficiency.

Vlontzos and Theodoridis (2013) in their work measured the efficiency and the productivity change of Greek dairy firms, using non parametric approaches. This assessment was achieved by the computation of the CRS and the VRS DEA models, the context dependent DEA approach and finally, the evolution of the Malmquist productivity index. These empirical analyses based on data from 29 Greek dairy firms. They concluded that the average efficiency score is 0.73 and 0.81 under the CRS and VRS DEA model suggests that there is space for improvement regarding the allocation of the available resources. Also, results of this empirical studies showed that there was 
significant difference in efficiency scores between firms producing dairy products in the Greek and the main milk producers of the EU, such as Germany and France.

Since Farrell defined the economic efficiency as product of technical efficiency (TE) and the allocative efficiency (AE), empirical analysis of firm efficiency broaden in most areas of economy. Technical efficiency is principal element in economic profitability as it measures the ability of the firm to produce maximal output from a given set of inputs. This will be reflected in the average cost of operation and, hence, will directly affect the competitive position of the firm (Ben-Belhasenn, 2000). Allocative efficiency reflects the ability of the firm to use the inputs in optimal proportions, given their respective prices. The allocative efficiency is necessary if the firm maximizes its profits or minimizes its costs at a given level of production (Ouattara, 2012).

DEA method is most often applied to analysis data on a sample of firms. It is a data oriented, non-parametric, deterministic approach for evaluating the performance of a set of peer entities called Decision Making Units (DMUs) (Cooper et al., 2004). DMUs are usually defined as entities responsible for turning input(s) into output(s), such as firms and production units (Kumar, Gulati, 2008). Unlike other methods (e.g. traditional regression methods) DEA constructs a frontier by comparing the data of each DMU with data of benchmark DMUs that perform better. (Hambrusch et al.,2006).

Since, Farrell (1957) introduced a concept to measure relative efficiency, two types of DEA model with integrated linear programming were developed. First was developed by Charnes et al. (1978) with assumed constant returns to scale (CRS). Second DEA model with variable returns to scale (VRS) was developed by Banker et al. (1984). Taking in account that various factors influence that DMUs not operating on optimal scale VRS is usually considered as more appropriate assumption.

DEA method has been widely used in dairy farms efficiency studies (Fraser, Cordina, 1999; Barnes, 2006; Minh, Long, 2009; D’Haese et al., 2009). Fraser, Cordina (1999) emphasise a several reason for using DEA analysis to measure dairy farm efficiency. Firstly, it is proposed that DEA is a useful tool in helping to identify key areas of interest in relation to extension efforts. Secondly, the type of information generated by DEA is detailed in relation to input use and the optimal factor mix, the identification of efficient farms within a sample and which farms are of most importance when it comes to benchmarking. Thirdly, in the last couple of years there has been a large increase in available computer software with which to undertake DEA. This software is easy to use and the results that are generated are easy to understand.

\section{Materials and methods}

Exploring efficiency of Serbian dairy industry in this paper is based on 2015 production year. The sample included 91 from 114 dairies. Number of dairy processing companies in sample represent $80 \%$ of all dairies, but its share in total milk processing in Serbia in 2015 was $98 \%$. In accordance with Law on accounting of the Republic of Serbia, 51 of them is classified as micro, 29 small 9 medium scale enterprises, and 2 of them classified 
as big enterprises. Data are provided from financial statements (balance sheet and income statements) published by Serbian Business Registers Agency (SBRA). Majority of 23 dairies not included in research are from group of micro enterprises that don't have obligation to publish financial statements. Some dairies without material, labor and energy cost, were excluded from research sample. In some cases dairy plants are smaller business of some companies, like in case Sava Kovačević, and it was not possible to separate dairy business from financially dominant part of other businesses.

Dairy companies in Serbia use various strategies. From sample data it can be inferred that some companies earns more revenue from row milk trade than from its processing. From sample, 18 dairy companies mainly from micro and some from small group of size earns more than half revenue from row milk sale to others. Those dairies collected row milk from farmers distribute mostly to big and medium size dairy processors.

Technical efficiency of dairy companies in Serbia is estimated by DEA input oriented, multi stage model with variable returns to scale (VRC). Comparing to the model with Constant return scale (CRS) it is more adequate to assume VRC approach since imperfect competition, government regulations, constraints on finance etc., may cause a firm to be not operating on optimal scale (Coelli et al, 2005). Each company in sample is treated as decision making unit (DMU), although some authors prefer term "firm". Model assume data on $N$ inputs and $M$ outputs for each $I$ DMU. For the I-th DMU these are represented by the column vectors $x_{i}$ and $q_{i}$, respectively. The $N$ x $I$ input matrix and the $M \times I$ output matrix, Q, represent the data for all $I$ DMU. For each DMU ratio of all outputs over all inputs could be obtained by $\mathrm{u}^{\prime} \mathrm{q}_{\mathrm{i}} / \mathrm{v}^{\prime} \mathrm{x}_{\mathrm{i}}$, where $\mathbf{u}$ is an $M \mathrm{x} 1$ vector of output weights and $\mathbf{v}$ is a $N \times 1$ vector of input weights. The optimal weights are obtained by solving mathematical programming problem:

$$
\begin{aligned}
& \max _{\mathrm{u}, \mathrm{v}}\left(\mathrm{u}^{\prime} \mathrm{q}_{\mathrm{i}} / \mathrm{v}^{\prime} \mathrm{x}_{\mathrm{i}}\right), \\
& \mathrm{st}^{3} \quad \mathrm{u}^{\prime} \mathrm{q}_{\mathrm{j}} / \mathrm{v}^{\prime} \mathrm{x}_{\mathrm{j}} \leq 1, \quad j=1,2, \ldots, I, \\
& \mathrm{u}, \mathrm{v} \geq 0 .
\end{aligned}
$$

Values for $\mathbf{u}$ and $\mathbf{v}$, such that the efficiency measure for the $i$-th DMU is maximised, subject to the constraints that all efficiency measures must be less than, or equal to one. To avoid infinite number of solutions in the ratio formulation it is necessary to impose constraint $\mathbf{v}^{\prime} \mathbf{x}_{\mathbf{i}}=\mathbf{1}$, which provides:

$$
\begin{aligned}
& \max _{\mu, v}\left(\mu^{\prime} \mathrm{q}_{\mathrm{i}}\right), \\
& \text { st } \quad v^{\prime} \mathrm{x}_{\mathrm{j}}=1, \\
& \mu \mathrm{q}_{\mathrm{j}} / v^{\prime} \mathrm{x}_{\mathrm{j}} \leq 1, \quad j=1,2, \ldots, I, \\
& \mu, v \geq 0 .
\end{aligned}
$$

3 "st" stends for Subject to 
Change of notation from $\mathbf{u}$ and $\mathbf{v}$ to $\boldsymbol{\mu}$ and $\boldsymbol{v}$ is used to stress that this is a different linear programming problem. Using duality in linear programming and convexity constraint $\mathbf{I 1}^{\prime} \lambda=\mathbf{1}$ DEA model is derived in form:

$$
\begin{array}{ll}
\min _{\square, \lambda} \square, \\
\text { st } \quad-\mathrm{q}_{\mathrm{i}}+\mathrm{Q} \lambda \geq 0, \\
& \square \mathrm{x}_{\mathrm{i}}-\mathrm{X} \lambda \geq 0, \\
& \mathrm{I} 1^{\prime} \lambda=1 \\
& \lambda \geq 0,
\end{array}
$$

where I1 is an I x 1vector of ones (Coelli et al, 2005). Linear programming problem must be solved I times, once for each DMU in the sample. A value of $\square$ is than obtained for each DMU.

The proposed DEA model enable calculation of CRS and VRS models for each DMU, that presents technical efficiency (TE) and pure technical efficiency (PTE) respectively. Scale efficiency is the ratio of TE and PTE. If ratio is equal to 1 than DMU is scale efficient, otherwise results lower than 1 indicate scale inefficiency. Also TE and PTE are bounded by zero and one, where coefficient one stands for efficient DMU.

\section{Results and discussion}

Output products are multiple in dairy industry, but on input side the most important single input is raw milk. One of often proposed conditions to chose output and inputs is that their total number should not be bigger than one third of DMU-s number in sample (Cooper et al, 2001). As output variable is analyzed business revenue earned in 2015. Business revenue includes revenue from dairy products sold and revenue from commodities sold. The main commodity that dairy companies trade is raw milk. Business revenue is proved as more adequate output measure than profit. It is because profit varied strongly among dairy companies from year to year, and can be negative.

Chosen input variables used in DEA model cover all input side of dairy processing business. First one input variable is cost of material, which is dominant cost component in the most dairy companies. As input variable it includes cost of all purchased materials used in production process. In the structure of material cost, raw milk purchased from farmers have the biggest share. Cost of raw milk as main input could have share in total cost of dairy companies, ranging from $60 \%$ to $80 \%$, depending on plant size and products structure (Popovic, Knezevic, 2010).

Second input, labour cost includes all range of cost varieties connected with labour used in dairy plant. According share in total production cost in dairy business it is second large cost. Third input is energy cost. All energy cost in raw milk transport, milk processing and transport of dairy products to market are included in this category. Fourth input variable is category of other costs. It includes five costs categories: depreciation, cost of purchased commodities, contracted services, non material cost, and interest paid. 
Table 1. provide descriptive statistics for output input variables of dairy industry in Serbia during 2015. There is huge variation of data from micro to big dairy companies, while cost shares in each DMU are relatively stable. Data in Table 2 proves that situation with strong correlation coefficients between input variables and between inputs and output data.

Table 1. Descriptive statistics for variables of 91 DMU, used in DEA method.

\begin{tabular}{|l|r|r|r|r|}
\hline Variable & \multicolumn{1}{|l|}{ Mean } & Standard deviation & \multicolumn{1}{l|}{ Minimum } & \multicolumn{1}{l|}{ Maximum } \\
\hline Return & 649,136 & $2,704,763$ & 136 & $24,758,079$ \\
\hline Raw material & 373,114 & $1,433,225$ & 0 & $12,967,554$ \\
\hline Labour & 51,081 & 216,680 & 179 & $1,982,685$ \\
\hline Energy & 29,443 & 103,719 & 0 & 923,788 \\
\hline Other cost & 155,606 & 680,643 & 195 & $6,236,403$ \\
\hline
\end{tabular}

Source: Data from financial statements of dairy companies published on SEBRA

The strongest correlation (Table 2) exist in relation revenue and material cost, what is expectable, since row milk as main input have $57 \%$ share in total cost of dairy plants for all DMUs. Sarkis (2007) propose that number of highly correlated inputs or outputs can be reduced in case of high correlation, but also warning that even in cases of perfect correlation of variables, results of efficiency estimate can slightly differ.

Table 2. Correlation analysis of input and output variables for $91 \mathrm{DMU}$.

\begin{tabular}{|l|l|l|l|l|l|}
\hline & Revenue & Material cost & Labour cost & Energy cost & Other cost \\
\hline Revenue & 1 & & & & \\
\hline Material cost & 0.9966 & 1 & & & \\
\hline Labour cost & 0.9932 & 0.9871 & 1 & & \\
\hline Energy cost & 0.9827 & 0.9817 & 0.9804 & 1 & \\
\hline Other cost & 0.9921 & 0.9806 & 0.9845 & 0.96462 & 1 \\
\hline
\end{tabular}

Source: Author's calculation based on SEBRA data.

DAEP 2.1 program (Coelli, 1996) was used to estimate DEA model with relative efficiency in sample of dairy processing companies in Serbia in 2015. Input - oriented multi stage model with variable return to scale was chosen for analysis. The results of CRS and VRS DEA models presents TE and PTE respectively. Scale efficiency is calculated as the ratio of TE and PTE.

The results of estimated DEA models for 91 DMUs, with CRS and VRS are presented in Table 3. Average TE calculated with CRS assumption is 0.838 , where 15 DMUs scored $\mathrm{TE}_{\mathrm{CRS}}=1$, mostly in groups of micro, small and middle sized dairy companies. Decomposition of $\mathrm{TE}_{\mathrm{CRS}}$ on PTE and scale efficiency revealed additional set of results.

DEA model estimated with VCR assumption have slightly higher efficiency 0.878 , while number of DMUs with $\mathrm{TE}_{\mathrm{VRS}}=1$ increased to 24 DMUs, where additional increase comes from groups of big, middle sized and small dairy companies. Considering this model, treated as PTE, results imply that inefficient companies may reduce inputs without a reduction in output. It is particularly important in case of micro dairies which 
are most input inefficient, and where inputs can be reduced for $14.7 \%$. In group of small sized dairies inputs can be reduced by $9.3 \%$, while in group of middle dairies inputs can be reduced for $4.8 \%$, keeping same level of output. The two biggest dairies are proved as efficient in inputs use.

Table 3. Technical efficiency scores by DEA method of dairy processors in Serbia for 2015.

\begin{tabular}{|l|c|r|r|r|l|}
\hline $\begin{array}{l}\text { En t e r p r is e } \\
\text { size }\end{array}$ & \multicolumn{1}{l|}{ DMU } & \multicolumn{1}{l|}{ CRS TE } & \multicolumn{1}{l|}{ VRS TE } & \multicolumn{1}{l|}{ Scale } & \\
\hline Micro & 51 & 0.801 & 0.843 & 0.947 & irs \\
\hline Small & 29 & 0.880 & 0.907 & 0.971 & drs \\
\hline Middle & 9 & 0.895 & 0.952 & 0.941 & drs \\
\hline Big & 2 & 0.929 & 1.000 & 0.929 & drs \\
\hline Mean: & & 0.838 & 0.878 & 0.954 & drs \\
\hline
\end{tabular}

Source: DAEP 2.1 program results

All dairy companies beside those 15 , which are technically efficient have another way to improve business results by changes in scale of business. Scale efficiency coefficients lower than one implying inefficiency. In the group of micro dairies (Table 3) the most of inefficient DMUs operate under increasing return to scale conditions. That is because those dairies are too small in its scale of operation, and way to increase its productivity is to increase size of business.

The most scale inefficient dairies in group of small, and all dairies in groups of middle and big dairy plants operate under decreasing return to scale conditions. 27 Companies from those three size groups are over dimensioned, i.e. above optimal productive scale. Approach to increase productivity to optimal level for this group of dairy companies is to decrease in size.

Two the biggest dairy companies have in average pure technical efficiency score, but they had the most to decrease in size to achieve optimal level of productivity.

Figure 1. Efficiency score distribution of 91 dairy companies in Serbia.

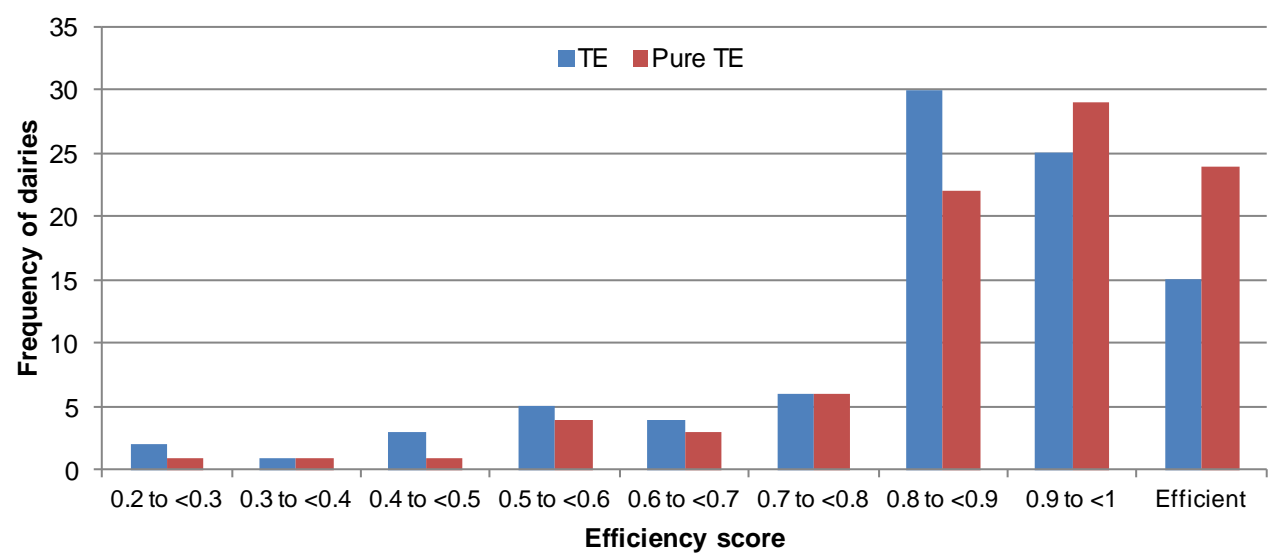

Source: Data obtained from DEA analysis. 
In Graph 1 are presented efficiency score distribution. From all dairies in sample 21 company have more significant problem with TE scored lower than 0.8 , while 16 of them have lower PTE than 0.8. Those farms are mainly from group of micro dairies, while several are from small and middle sized dairies. It is important to emphasise that efficient dairies exists in all range of company size.

\section{Conclusions}

The paper examine relative inter efficiency of Serbian dairy processing companies. The empirical results reveal differences in technical efficiency scores among dairy companies through size groups. Only 15 companies are efficient with extension on 24 that have pure technical efficiency. The two different approaches to increase efficiency were identified. First, to make input reduction, keeping same level of output, what is especially important for micro and small dairies, with smaller effect on middle dairies. Second approach, is to change size of business to optimal level. The most of inefficient dairies in group of micro should to increase size of business, while all big and middle, as well as most of inefficient small dairies had to decrease size of business to optimal level of productivity.

Chosen input and output variables represent well dairy business. Input variables used in model cover all cost structure in milk processing industry. Strong correlation between inputs used in model were expectable since cost shares in dairy industry are stable.

Although, different business strategies of dairy companies were identified through research, in this paper its technical efficiency were not analysed according applied strategies. Another recommendation or open question for further research is how to decompose inputs and outputs on price and quantity, what will enable analysis of economic efficiency in dairy sector.

\section{Acknowledgements}

This study was supported by Ministry of Education, Science and Technological Development of the Republic of Serbia, Projects No. III 46006 and III 46009.

\section{Conflict of interests}

The authors declare no conflict of interest.

\section{References}

1. Aldeseit, B. (2013). Measurement of Scale Efficiency in Dairy Farms: Data Envelopment Analysis (DEA) Approach. Journal of Agricultural Science; 5 (9), 37-43. DOI: 10.5539/jas.v5n9p37

2. Barać, Ž., Muminović, S. (2013). The impact of capital investments on dairy processing industry features: evidence from Slovenia, Croatia and Serbia. Mljekarstvo 63 (3), 140-149. URI https://hrcak.srce.hr/106564 
3. Al-Sharafat,A.(2013).TechnicalEfficiency ofDairy Farms:AStochastic Frontier Applicationon Dairy Farms in Jordan. JournalofAgriculturalScience 5(3), 45-53. DOI: 105539/jas.v5n3p45

4. Banker, R., Charnes, A., Cooper, W. (1984). Some models for estimating technical and scale inefficiencies in data envelopment analysis. Management science, 30(9), 1078-1092. DOI: 10.1287/mnsc.30.9.1078

5. Baran, J. (2013). Efficiency of the production scale of polish dairy companies based on data envelopment analysis. Oeconomia 12 (2), 5-13. ISSN 16440757

6. Barnes, A. P. (2006). Does multi-functionality affect technical efficiency? A non-parametric analysis of the Scottish dairy industry. Journal of Environmental Management, 80, 287-294. DOI: 10.1016/j.jenvman.2005.09.020

7. Ben-Belhasenn, B. (2000). Measurement and Explanation of Technical Efficiency in Missouri Hog Production. American Agricultural Economics Association (AAEA), Annual Meeting, Tampa, Florida, July 30-Avgust 2. http://ageconsearch.umn.edu/record/21819

8. Business register agency, (2017). Yearly financial reports, Available at: http:// pretraga2.apr.gov.rs/pretragaObveznikaFI/

9. Candemir, M., Koyubenbe, N. (2013). Efficiency Analysis of Dairy Farms in the Province of Izmir (Turkey): Data Envelopment Analysis (DEA), Journal of Applied Animal Research, 29 (1), 61-64. DOI: 10.1080/09712119.2006.9706572

10. Charnes, R., Cooper, W., Rhodes, E. (1978). Measuring the efficiency of decision making units. European Journal of Operational Research 2, 429-444. DOI: $10.1016 / 0377-2217(78) 90138-8$

11. Coelli, T. (1996). A guide to DEAP Version 2.1. A Data Envelopment Analysis Computer Program, Centre for Efficiency and Productivity Analysis, Department of Econometrics, University of New England, Armidale, Australia. ISSN 1327-435X

12. Coelli, T., J., Rao, P., D., S., O’Donnell, C., J., Battese, G., E. (2005). An introduction to efficiency and productivity analysis, Springer, USA. ISBN-10: 0-387-24265-1

13. Cooper, W.W., Li S., Seiford, L.M., Tone, K., Thrall, R.M., Zhu, J. (2001). Sensitivity and stability analysis in DEA: some recent developments, Journal of productivity analysis, 15 (3), 217-246.

14. Cooper, W.W., Seiford, L.M. and Zhu, J. (2004). Handbook on Data Envelopment Analysis. Springer, Kluwer Academic Publishers, Boston.

15. D’Haese, M., Speelman, S., Alary, V., Tillard, E., \& D’Haese, L. (2009). Efficiency in milk production on Reunion Island: Dealing with land scarcity. Journal of Dairy Science, 92, 3676-3683. DOI: 10.3168/jds.2008-1874 
16. Farrell, M. J. (1957). The Measurement of Productive Efficiency. Journal of the Royal Statistical Society, 120, 253-281. DOI: 10.2307/2343100

17. Fraser, I., Cordina, D. (1999). An application of data envelopment analysis to irrigated dairy farms in Northern Victoria. Agricultural Systems 59, 267-282. DOI: 10.1016/S0308- 521X(99)00009-8

18. Hambrusch, J., Kirner, 1., Ortner, K.M. (2006). Technical and scale efficiency in Austrian dairy farming. Economic Science for Rural Development (10), 4249. ISSN : 1691-3078

19. Hemme, T. (2016). IFCN Dairy Report 2016. International farm comparison network, IFCN Dairy research center, Kiel, Germany.

20. Kelly, E., Shalloo, L., Geary, U., Kinsella, A., Wallace, M. (2012). Application of data envelopment analysis to measure technical efficiency on a sample of Irish dairy farms. Irish Journal of Agricultural and Food Research 51 (1), 6377. DOI: $10.2307 / 41756846$

21. Kumar, S., Gulati, R. (2008). An Examination of Technical, Pure Technical, and Scale Efficiencies in Indian Public Sector Banks using Data Envelopment Analysis, Eurasian Journal of Business and Economics, 1 (2), 33-69.

22. Law on accounting of the Republic of Serbia („Official gazette RS”, no. 62/2013),

23. Minh, N. K., \& Long, G. T. (2009). Efficiency Estimates for Agricultural Production in Vietnam: A Comparison of Parametric and Non parametric Approaches. Agricultural Economics Review, 10, 62-78.

24. Ouattara, W. (2012). Economic Efficiency Analysis in Côte d'Ivoire, American Journal of Economics, 2 (1), 37-46.

25. Popovic, R. (2006). An Economic Efficiency In Vojvodina Dairy Production. Economics of Agriculture, Belgrade, 53(3), 869-877.

26. Popovic, R. (2013). Economic efficiency of dairy farms with intensive and grazing production systems. Book of proceedings the Seminar: Agriculture and rural development - challenges of transition and integration processes, Belgrade 26-28.9.2013. pp. 205-213.

27. Popovic, R. (2014). Structure of farms with livestock enterprises and its importance for agricultural policy. Book of proceedings the Conference: Utilization of the Census of Agriculture 2012 data in analyzing status of agriculture and agricultural policy making in the Republic of Serbia, Subotica 28-30 May 2014, page 325-339 ISBN-978-8686-6161-115-5 Available at: http://popispoljoprivrede.stat.rs/?page_id=5173

28. Popovic, R., Panic D. (2015). Innovative strategies of SMEs food industry in Serbia. Proceedings of the workshop at AgriMBA network Congress ,Smart Agribusiness for Society of Tomorrow“, Porec, Croatia, 17 and 18 June 2015, FAO. Available at: http:/www.fao.org/fileadmin/user_upload/Europe/ documents/Publications/AFC_EECA_en.pdf 
29. Popovic, R., Radovanov, B. (2010). Price transmission in Serbian dairy chain. Economics of agriculture, 57 (4), 543-554. ISSN 0352-3462

30. Sarkis, J. (2007). Preparing your data for DEA. Modelling data irregularities and structural complexities in Data envelopment analysis. Springer, New York, USA.

31. Silva, E., Arzubi, A., Berbel, J. (2004). An Application of Data Envelopment Analysis (DEA) in Azores Dairy Farms, New Medit3, 39-43. DOI: 10.1007/97894-007-5739-4-5

32. Soboh, R., Lansink, A., Dijk, G. (2014). Efficiency of European dairy processing firms. Wageningen Journal of live sciences, 70-71, 53-59.

33. Špička, J. (2015). The Efficiency Improvement of Central European Corporate Milk Processors in 2008 - 2013, Agris on-line Papers in Economics and Informatics 8 (4), 175-188.

34. Vlontzos, G., Theodoridis, A. (2013). Efficiency and Productivity Change in the Greek Dairy Industry, Agricultural Economics Review 14 (2), 14-28. ISSN: 1109-2580 